\title{
Circulating microRNAs as a liquid biopsy: a next- generation clinical biomarker for diagnosis of gastric cancer
}

\author{
Shuhei Komatsu', Jun Kiuchi', Taisuke Imamura', Daisuke Ichikawa², Eigo Otsuji' \\ 'Division of Digestive Surgery, Department of Surgery, Kyoto Prefectural University of Medicine, Kawaramachihirokoji, Kamigyo-ku, \\ Kyoto 602-8566, Japan. \\ ${ }^{2}$ First Department of Surgery, Faculty of Medicine, University of Yamanashi, Chuo, Yamanashi 409-3898, Japan. \\ Correspondence to: Dr. Shuhei Komatsu, Division of Digestive Surgery, Department of Surgery, Kyoto Prefectural University \\ of Medicine, 465 Kajii-cho, Kawaramachihirokoji, Kamigyo-ku, Kyoto 602-8566, Japan. E-mail: skomatsu@koto.kpu-m.ac.jp
}

How to cite this article: Komatsu S, Kiuchi J, Imamura T, Ichikawa D, Otsuji E. Circulating microRNAs as a liquid biopsy: a nextgeneration clinical biomarker and treatment target in gastric cancer. J Cancer Metastasis Treat 2018;4:36.

http://dx.doi.org/10.20517/2394-4722.2017.58

Received: 18 Oct 2017 Accepted: 14 Jul 2018 Published: 18 Jul 2018

Science Editors: Lucio Miele, Masayuki Watanabe Copy Editor: Jun-Yao Li Production Editor: Cai-Hong Wang

\begin{abstract}
Accumulating evidence has suggested the potential clinical utility of novel body fluid biomarkers, or "liquid biopsy", using circulating tumor cells and cell-free nucleic acids from cancer patients. Noninvasive and reproducible, liquid biopsy could provide the basis for individualized therapeutic strategies by identifying genetic and epigenetic aberrations that are closely associated with cancer initiation and progression. MicroRNAs (miRNAs) are short noncoding RNAs that posttranscriptionally regulate gene expression. They also play important roles in various physiological and developmental processes as oncogenic or tumor-suppressive regulators. Specific miRNA expression signatures have been identified in a number of human cancers. Circulating miRNAs have been detected in plasma and serum, and this in blood has attracted the attention of researchers for their potential as noninvasive biomarkers. Circulating miRNAs have emerged as tumorassociated biomarkers that reflect not only the existence of cancer, but also the dynamics, malignant potential, and drug resistance of tumors. Herein, we review the recent biological and clinical research on the circulating miRNAs of gastric cancer and discuss future perspectives for their clinical applications as a liquid biopsy.
\end{abstract}

Keywords: Liquid biopsy, circulating nucleic acids, circulating microRNA, biomarker, gastric cancer

\section{INTRODUCTION}

Gastric cancer is third-leading cause of death among all cancers worldwide ${ }^{[1]}$. While improved perioperative management and diagnostic techniques have boosted early detection and decreased mortality in recent years,

\footnotetext{
(ㅇ) (1)

(C) The Author(s) 2018. Open Access This article is licensed under a Creative Commons Attribution 4.0 International License (https://creativecommons.org/licenses/by/4.0/), which permits unrestricted use, sharing, adaptation, distribution and reproduction in any medium or format, for any purpose, even commercially, as long as you give appropriate credit to the original author(s) and the source, provide a link to the Creative Commons license, and indicate if changes were made.
}

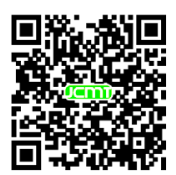


gastric cancer continues to constitute a global health problem as a prevalent form of cancer ${ }^{[1]}$. Gastric cancer patients at advanced stages of the disease have a very poor prognosis ${ }^{[2]}$. Despite these continued difficulties, no biomarker molecule has been employed for the early diagnosis of gastric cancer in clinical settings, and researchers have validated only a scant number of molecules as therapeutic targets ${ }^{[3-7]}$. Therefore, for gastric cancer, identifying novel molecular targets and clinical biomarkers remain vital clinical challenges.

Recently, the concept of a "liquid biopsy" has become widely accepted in the clinical setting. Liquid biopsy is a less approaches for obtaining genetic and epigenetic aberrations that are closely associated with cancer initiation and progression ${ }^{[8]}$. Moreover, liquid approaches allows for repeated sampling and this makes it possible to evaluate the longitudinal evolution of a tumor and its heterogeneous characteristics, which single sampling may fail to capture ${ }^{[9-13]}$. Understanding circulating tumor cells and cell-free nucleic acids in cancer patients may bring new insights into prognostic and predictive value of liquid biopsy. In this article, we review recent research on the circulating miRNAs of gastric cancers, and discuss future perspectives on next-generation clinical biomarkers and treatment targets in gastric cancer.

\section{THE MOLECULAR FEATURES AND BIOLOGICAL SIGNIFICANCE OF MICRORNAS}

Small noncoding RNAs known as microRNAs (miRNAs) regulate how specific protein-coding genes are translated. After miRNAs were discovered in $1993^{[14]}$, researchers have correlated changes in miRNA expression with diseases progression in multiple forms of cancer ${ }^{[15-18]}$. Numerous recent studies have detailed how miRNAs can be detected in plasma/serum while keeping their impressive stability ${ }^{[16,19-22]}$. Plasma/serum miRNAs resist endogenous ribonuclease activity through binding with plasma proteins such as Argonaute 2 and high-density lipoprotein $(\mathrm{HDL})^{[23,24]}$ or being surrounded by different secretory vesicles, including plasma/serum exosomes and apoptotic bodies ${ }^{[19,25-27]}$. Thus, miRNAs in peripheral blood are not digested by RNase or damaged by other conditions such as low or high $\mathrm{pH}$, extended storage, boiling, and multiple freeze-thaw cycles. In addition, numerous extracellular miRNAs are made present by active secretion in addition to cell lysis ${ }^{[10,28,29]}$; such miRNAs are able to play a role as intercellular transmitters ${ }^{[2,28,30,31]}$. As one possible mechanism, the extracellular miRNAs involved in exosome vesicles has been reported to be released through ceramide-dependent secretory systems and function in recipient cells ${ }^{[29]}$.

\section{CIRCULATING MICRORNAS ARE A PROMISING SOURCE OF DIAGNOSTIC AND PROGNOSITC INFORMATION IN SOLID TUMORS}

Mitchell et al.$^{[19]}$ first reported that circulating miRNAs had potential utility as new biomarkers in patients with solid cancers. As noninvasive and reproducible biomarkers in cancer patients, circulating miRNAs have since attracted the attention of researchers. As indicated by the usefulness of cell-free DNA and circulating tumor cells, the concept of "liquid biopsy" through circulating miRNAs may also provide ideal individualized therapeutic strategies for cancer patients and contribute to the development of precision medicine. Indeed, previous studies, including our own, have identified various blood-based miRNA biomarker candidates, which are useful for cancer detection, monitoring tumor dynamics, and predicting malignant potential, prognosis, and chemoresistance in cancer patients ${ }^{[32-45]}$.

\section{HIGH LEVELS OF CIRCULATING MICRORNAS IN PLASMA/SERUM IN GASTRIC CANCER}

Various studies have identified circulating miRNAs for use in the diagnosis and prognosis of gastric cancer patients [Table 1]. In 2010, we reported the usefulness of circulating miRNAs and demonstrated their feasibility as biomarkers in the plasma of patients with gastric cancer. We selected four miRNAs (miR-17-5p, $21,106 \mathrm{a}$, and 106b) that has been previously reported as upregulated in gastric cancer tissues, analyzed their levels in plasma using RT-qPCR, and confirmed their utility as diagnostic biomarkers ${ }^{[32]}$. We then identified plasma miR-451 and miR-486 as novel cancer screening markers using the Toray ${ }^{\circledR} 3 \mathrm{D}-\mathrm{Gene}$ microRNA 
Table 1. High level of circulating microRNAs in plasma/serum in gastric cancer

\begin{tabular}{|c|c|c|c|c|c|c|}
\hline $\mathbf{m i R}$ & Sample & Ethnicity & $\begin{array}{l}\text { Gastric cancer } \\
\text { patietns }\end{array}$ & Controls & Value & Ref. \\
\hline \multirow[t]{3}{*}{ miR-16 } & Plasma & China & 200 & 200 & $\mathrm{D}$ & Zhu et al. 2014 \\
\hline & & China & 50 & 47 & $\mathrm{D}$ & Wang et al. 2014 ${ }^{[69]}$ \\
\hline & & China & 155 & 111 & $\mathrm{D}$ & Zhang et al. 2015 ${ }^{[58]}$ \\
\hline \multirow[t]{3}{*}{ miR-17-5p } & Plasma & Japan & 69 & 30 & D & Tsujiura et al. 2010 ${ }^{[32]}$ \\
\hline & & China & 65 & NA & $P, M$ & Wang et al. 2012 ${ }^{[70]}$ \\
\hline & All blood & China & 90 & 27 & D & Zhou et al. 2010[71] \\
\hline miR-18a & Plasma & Japan & 104 & 65 & $D, M$ & Tsujiura et al. $2015^{[40]}$ \\
\hline miR-19b & Plasma & China & 155 & 111 & $\mathrm{D}$ & Zhang et al. $2015^{[58]}$ \\
\hline \multirow[t]{4}{*}{ miR-20a } & Plasma & China & 65 & NA & $P, M$ & Wang et al. 2012 ${ }^{[70]}$ \\
\hline & & China & 60 & 60 & $\mathrm{D}$ & Cai et al. $2013^{[72]}$ \\
\hline & & China & 101 & 91 & $\mathrm{D}$ & Zhou et al. 2015 ${ }^{[73]}$ \\
\hline & Serum & China & 55 & 55 (post-operative) & $P, M$ & Yang et al. $2017^{[74]}$ \\
\hline \multirow[t]{9}{*}{ miR-21 } & Plasma & Japan & 69 & 30 & $D, P$ & $\begin{array}{l}\text { Tsujiura et al. 2010 } \\
\text { Komatsu et al. 2013 }\end{array}$ \\
\hline & & China & 70 & 70 & $\mathrm{D}$ & Li et al. 2012 \\
\hline & & China & 53 & 20 & $\mathrm{D}$ & Zheng et al. ${ }^{[48]}$ \\
\hline & Serum & China & 174 & 39 & $\mathrm{D}$ & Wang et al. 2012 \\
\hline & & Japan & 87 & 114 & $\mathrm{D}$ & Shiotani et al. $2013^{[77]}$ \\
\hline & & China & 103 & NA & $M$ & Song et al. $2013^{[78]}$ \\
\hline & & China & 50 & 50 & $D$ & Wu et al. 2015 $5^{[57]}$ \\
\hline & & China & 92 & 89 & $\mathrm{D}$ & Huang et al. 2016 ${ }^{[79]}$ \\
\hline & & Poland & 20 & 20 & $D$ & Sierzega et al. 2017 ${ }^{[80]}$ \\
\hline miR-23b & Plasma & China & 138 & 50 & $D, P$ & Zhuang et al. 2016 $6^{[81]}$ \\
\hline \multirow[t]{4}{*}{ miR-25 } & Plasma & China & 200 & 200 & $\mathrm{D}$ & Zhuet al. 2014 ${ }^{[55]}$ \\
\hline & & China & 20 & 20 & $D, P$ & Zhang et al. 2014 ${ }^{[82]}$ \\
\hline & & China & 101 & 91 & $\mathrm{D}$ & Zhou et al. $2015^{[73]}$ \\
\hline & & China & 65 & 65 & $D$ & Li et al. 2017 \\
\hline $\operatorname{miR}-92 a$ & Plasma & China & 200 & 200 & $\mathrm{D}$ & Zhu et al. $2014^{[55]}$ \\
\hline miR-92b & Plasma & China & 101 & 91 & $D$ & Zhou et al. $2015^{[73]}$ \\
\hline \multirow[t]{2}{*}{ miR-93 } & Plasma & China & 65 & 65 & $\mathrm{D}$ & Li et al. $2017^{[83]}$ \\
\hline & & China & 20 & 20 & $D, P$ & Zhang et al. 2014 ${ }^{[82]}$ \\
\hline miR-100 & Serum & China & 50 & 47 & $\mathrm{D}$ & Wang et al. 2014 ${ }^{[69]}$ \\
\hline \multirow[t]{2}{*}{ miR-106 } & Serum & Japan & 87 & 114 & $\mathrm{D}$ & Shiotani et al. $2013^{[77]}$ \\
\hline & & China & $\begin{array}{l}118 \text { (with } \\
\text { chemotherapy) }\end{array}$ & $\begin{array}{l}20 \text { (without } \\
\text { chemotherapy) }\end{array}$ & $P$ & Song et al. $2017^{[84]}$ \\
\hline \multirow[t]{2}{*}{ miR-106a } & Plasma & Japan & 69 & 30 & $\mathrm{D}$ & Tsujiura et al. 2010 \\
\hline & All blood & China & 90 & 27 & $D$ & Zhou et al. 2010 $[71]$ \\
\hline \multirow[t]{4}{*}{ miR-106b } & Plasma & Japan & 69 & 30 & $\mathrm{D}$ & Tsujiura et al. $2010^{[32]}$ \\
\hline & & China & 60 & 60 & $\mathrm{D}$ & Cai et al. $2013^{[72]}$ \\
\hline & & China & 20 & 20 & $D, P$ & Zhang et al. 2014 ${ }^{[82]}$ \\
\hline & & China & 65 & 65 & $\mathrm{D}$ & Li et al. 2017 \\
\hline miR-107 & Serum & Iran & 36 & 36 & $\mathrm{D}$ & Ayremlou et al. 2015 \\
\hline miR-181c & Plasma & China & 30 & $\begin{array}{l}60 \text { (30 gastric ulcer } \\
\text { and } 30 \text { gastritis) }\end{array}$ & $\mathrm{D}$ & Cui et al. 2013 ${ }^{[85]}$ \\
\hline miR-185 & Plasma & China & 101 & 91 & $\mathrm{D}$ & Zhou et al. $2015^{[73]}$ \\
\hline miR-191 & Serum & China & 57 & 58 & $\mathrm{D}$ & Peng et al. $2014^{[86]}$ \\
\hline miR-192 & Plasma & China & 96 & 36 & D & Chen et al. 2014 ${ }^{[52]}$ \\
\hline miR-199a-3p & Plasma & China & 230 & 130 & $\mathrm{D}$ & Li et al. $2013^{[51,87]}$ \\
\hline \multirow[t]{2}{*}{ miR-200c } & All blood & Spain & 52 & 15 & $D, P$ & Valladares-Ayerbes et al. 2012 \\
\hline & Serum & China & 98 & 100 & $P$ & Zhang et al. $2015^{[88]}$ \\
\hline miR-210 & Plasma & China & 101 & 91 & $D$ & Zhou et al. 2015 \\
\hline miR-221 & Plasma & China & 60 & 60 & $\mathrm{D}$ & Cai et al. 2013 272$]$ \\
\hline miR-222 & Plasma & China & 114 & 56 & $D, P$ & Fu et al. $2014^{[53]}$ \\
\hline \multirow[t]{2}{*}{ miR-223 } & Plasma & China & 70 & 70 & $\mathrm{D}$ & Li et al. $2012^{[75]}$ \\
\hline & Serum & China & 50 & 47 & $D$ & Wang et al. $2014^{[69]}$ \\
\hline miR-331 & Serum & Poland & 20 & 20 & $D$ & Sierzega et al. 2017 \\
\hline $\operatorname{miR}-370$ & Plasma & Taiwan & 40 & 12 & $D$ & Lo et al. 2012 \\
\hline miR-378 & Serum & China & 40 & 41 & $\mathrm{D}$ & Liu et al. 2012 \\
\hline
\end{tabular}




\begin{tabular}{|c|c|c|c|c|c|c|}
\hline \multicolumn{2}{|l|}{ Page 4 of 10} & \multicolumn{5}{|c|}{ Komatsu et al. J Cancer Metastasis Treat 2018;4:36 I http://dx.doi.org/10.20517/2394-4722.2017.58 } \\
\hline miR-421 & Serum & China & 90 & 90 & D & Wu et al. 2015 5 [50] \\
\hline \multirow[t]{2}{*}{ miR-451 } & Plasma & Japan & 56 & 30 & D & Konishi et al. 2012 ${ }^{[46]}$ \\
\hline & & China & 200 & 200 & D & Zhu et al. 2014 $4^{[55]}$ \\
\hline \multirow[t]{2}{*}{ miR-486-5p } & Plasma & Japan & 56 & 30 & D & Konishi et al. 2012 \\
\hline & & China & 200 & 200 & $\mathrm{D}$ & Zhu et al. 2014 ${ }^{[55]}$ \\
\hline miR-664 & Serum & China & $\begin{array}{l}118 \text { (with } \\
\text { chemotherapy) }\end{array}$ & $\begin{array}{l}20 \text { (without } \\
\text { chemotherapy) }\end{array}$ & $P, M$ & Song et al. $2017^{[84]}$ \\
\hline
\end{tabular}

D: diagnostic value; P: prognostic value; M: monitoring value

array-based approach on pre- and postoperative samples ${ }^{[46]}$. The area under the curve (AUC) values for these markers were high, at 0.96 and 0.92 , respectively for the diagnosis of gastric cancer ${ }^{[46]}$. Additionally, genome-wide miRNA expression profiles followed by RT-qPCR assays revealed that circulating miR-378 had an AUC of 0.861 with $87.5 \%$ sensitivity and $70.73 \%$ specificity ${ }^{[47]}$. As shown in Table 1, many circulating miRNAs have been previously identified (by our group and others) as promising blood biomarker candidates for the detection of gastric cancer: miR-16, miR-17-5p, miR-18a, miR-19b, miR-20a, miR-21, miR-23b, miR25, miR-92a, miR-92b, miR-93, miR-100, miR-106, miR-106a, miR-106b, miR-107, miR181c, miR-185, miR191, miR-192, miR-199a-3p, miR-200c, miR-210, miR-221, miR-222, miR-223, miR-331, miR-370, miR-378, miR-421, miR-451, miR-486-5p, and miR-664, all of which are up-regulated in plasma/serum. These are promising diagnostic biomarkers ${ }^{[32,40,46-55,57,58,69-89]}$.

\section{LOW LEVEL OF CIRCULATING MICRORNAS IN PLASMA/SERUM IN GASTRIC CANCER}

Kosaka et al. ${ }^{[29,59,60]}$ recently suggested that healthy cells secrete some tumor-suppressor miRNAs as a way of slowing aberrant cell growth. We have previously found that blood-borne tumor-suppressor miRNAs, such as let$7 \mathrm{a}^{[32]}$ and miR-375 ${ }^{[35,45]}$ were significantly downregulated in comparison to those of normal volunteers. Circulating miRNAs are released from both normal and cancer tissues, and the majority of these tumor-suppressor miRNAs are thought to arise from normal tissues. We therefore hypothesize that the progression of cancer causes healthy cells to become depleted of some tumor-suppressor miRNAs. That hypothesis is supported by our previously data that shows that a decrease in the plasma level of the tumor-suppressor miR-375 in esophageal cancer patients ${ }^{[34]}$ and this ${ }^{[6]}$ is correlated with reduced survival. We have also proposed that tumor progression and the resultant poor prognostic outcomes are correlated with the downregulation of tumor-suppressor miRNAs in the bloodstream ${ }^{[34,35]}$. As shown in Table 2, various circulating tumor-suppressor miRNAs have previously been identified as promising blood biomarker candidates for the detection and diagnosis of gastric cancer. These include miR-15a, miR-17, miR-26a, miR-31, miR-92a, miR-93, miR-106b, miR-122, miR-181b, miR-195-5p, miR203, miR-204, miR-206, miR-218, miR-375, miR-503, miR-940, and let-7a, which are downregulated in plasma/ serum with a great degree of diagnostic ability ${ }^{[32,52,56,62,75,79,84,90-100]}$.

\section{CIRCULATING MICRORNAS RELATED TO MALIGNANT POTENTIAL, TUMOR RECURRENCE, AND PROGNOSIS BIOMARKERS IN PLASMA/SERUM IN GASTRIC CANCER}

Wang et al ${ }^{[70]}$ have reported that high levels of plasma miR-17-5p and miR-20a were significantly correlated with poor overall survival in gastric cancer patients. Valladares-Ayerbes et al. ${ }^{[4]}$ have also reported that higher expression levels of miR-200c in blood are associated with poor overall survival. We demonstrated that the postoperative cause-specific survival was significantly poorer in gastric cancer patients with high plasma miR-21 levels than in those with low levels ${ }^{[54]}$. Moreover, the incidence of vascular invasion was also slightly higher in gastric cancer patients with high miR-21 levels, and multivariate analysis revealed that the presence of high miR-21 plasma levels was an independent prognostic factor ${ }^{[54]}$. Therefore, various up-regulated circulating miRNAs have previously been identified as blood-based prognostic biomarkers for gastric cancer: miR-17-5p, miR-20a, miR-21, miR-23b, miR-25, miR-93, miR-106, miR-106b, miR-200c, miR222, and miR-664 [Table 1$]^{[49,53,54,70,74,81,82,84,88]}$. 
Table 2. Low level of circulating microRNAs in plasma/serum in gastric cancer

\begin{tabular}{|c|c|c|c|c|c|c|}
\hline miR & Sample & Ethnicity & $\begin{array}{c}\text { Gastric cancer } \\
\text { patietns }\end{array}$ & Control & Value & Ref. \\
\hline miR-15a & Serum & China & $\begin{array}{l}118 \text { (with } \\
\text { chemotherapy) }\end{array}$ & $\begin{array}{l}20 \text { (without } \\
\text { chemotherapy) }\end{array}$ & $P$ & Song et al. 2017 \\
\hline miR-17 & Serum & China & 40 & 36 & $\mathrm{D}$ & Zeng et al. 2014 ${ }^{[91]}$ \\
\hline miR-26a & Plasma & China & 285 & 285 & D & Qiu et al. 2016 ${ }^{[92]}$ \\
\hline miR-31 & Serum & China & 92 & 89 & D & Huang et al. 2016 ${ }^{[79]}$ \\
\hline miR-92a & Serum & China & 92 & 89 & D & Huang et al. $2016^{[79]}$ \\
\hline miR-93 & Serum & China & $\begin{array}{l}118 \text { (with } \\
\text { chemotherapy) }\end{array}$ & $\begin{array}{l}20 \text { (without } \\
\text { chemotherapy) }\end{array}$ & $P$ & Song et al. $2017^{[84]}$ \\
\hline miR-106b & Serum & China & 40 & 36 & D & Zeng et al. 2014 ${ }^{[91]}$ \\
\hline miR-122 & Plasma & China & 96 & 36 & D & Chen et al. 2014 ${ }^{[52]}$ \\
\hline miR-181b & Serum & China & 92 & 89 & $\mathrm{D}$ & Huang et al. 2016 \\
\hline \multirow[t]{2}{*}{ miR-195-5p } & Serum & China & 62 & 36 & $D, P$ & Shen et al. 2016 ${ }^{[93]}$ \\
\hline & Plasma & Turkey & 20 & 190 & $\mathrm{D}$ & Gorur et al. 2013 ${ }^{[94]}$ \\
\hline \multirow[t]{2}{*}{ miR-203 } & Serum & China & 92 & 89 & D & Huang et al. 2016 ${ }^{[79]}$ \\
\hline & & Japan & 130 & 22 & $P, M$ & Imaoka et al. 2016 ${ }^{[62]}$ \\
\hline miR-204 & Serum & China & 115 & 40 & $P, M$ & Chen et al. 2016 \\
\hline miR-206 & Serum & China & 150 & 150 & $\mathrm{D}$ & Hou et al. $2016^{[96]}$ \\
\hline \multirow[t]{2}{*}{ miR-218 } & Plasma & China & 70 & 70 & D & Li et al. 2012 $2^{[75]}$ \\
\hline & Serum & China & 68 & 56 & $\mathrm{P}$ & Xin et al. 2014 ${ }^{[97]}$ \\
\hline miR-375 & Serum & China & NA & NA & D & Zhang et al. 2012 ${ }^{[98]}$ \\
\hline miR-503 & Serum & China & 68 & 32 & $D, P$ & Wu et al. 2016 ${ }^{[99]}$ \\
\hline miR-940 & Plasma & China & 110 & 30 & $\mathrm{D}$ & Liu et al. 2016 ${ }^{[56]}$ \\
\hline \multirow[t]{2}{*}{ let-7a } & Plasma & Japan & 69 & 30 & $\mathrm{D}$ & Tsujiura et al. 2010 $[32]$ \\
\hline & Serum & China & 80 & NA & D & Wang et al. 2013 $3^{[100]}$ \\
\hline
\end{tabular}

D: diagnostic value; P: prognostic value; M: monitoring value

Regarding tumor-suppressor miRNAs, Imaoka et al. ${ }^{[62]}$ reported that serum expression of miR-203 was significantly lower in stage IV than in stages I-III of gastric cancer patients. Serum miR-203 expression was significantly lower in gastric cancer patients with worse malignant potential, as indicated by higher T stage, vessel invasion, and nodal, peritoneal, and distant metastases. Low expression of serum miR-203 was correlated with poor disease-free survival and overall survival. This low expression was an independent predictive marker for metastases, including nodal, peritoneal, and distant metastases, and a poor prognosis in gastric cancer patients ${ }^{[62]}$. Therefore, various downregulated circulating miRNAs have been identified as blood-based prognostic biomarkers for gastric cancer: miR-15a, miR-93, miR-195-5p, miR-203, miR-204, miR-218 and miR-503 [Table 2] ${ }^{[62,84,90,93,95,97,99]}$.

\section{DIFFERENT EXPRESSION LEVELS OF SOME CIRCULATING MIRNAS BETWEEN PLASMA AND}

\section{SERUM IN GASTRIC CANCER}

From the viewpoint of liquid biopsy using blood miRNAs, many issues must still be addressed before novel findings can be translated into clinically useful and noninvasive screening strategies for gastric cancer patients. Because plasma includes more abundant proteins, such as coagulation factors, than does serum, miRNA profiles in the plasma of cancer patients differ considerably from those in the serum ${ }^{[63]}$, as has been shown in esophageal cancer ${ }^{[37,64]}$ and pancreatic cancer ${ }^{[63]}$. In gastric cancer, the expression levels of some circulating miRNAs, such as miR-17, miR-92a, miR-93, and miR-106b, moved in opposite directions in the plasma and serum [Tables 1 and 2]. Although detailed mechanisms remain unknown, the data strongly suggest that these issues should be considered in future clinical applications of cancer treatments.

\section{FUTURE PERSPECTIVES ON CIRCULATING TUMOR-SUPPRESSOR MICRORNAS FOR TREATMENT TARGETS IN GASTRIC CANCER}

Multiple researchers have recently examined therapeutic miRNA-based drugs by using synthetic miRNA 
mimics $^{[101]}$. Various efforts have been made to develop miRNA-based therapies in the past several years, and two studies have shown particular promise. The first study focused on the therapeutic silencing of diseaseassociated miRNAs using miRNA inhibitors. Miravirsen (Santaris Pharma) is one of several promising miRNA inhibitors; it can bind to miR-122 and inhibit its biogenesis. Miravirsen was developed for the treatment of hepatitis $\mathrm{C}$ and is currently under evaluation in clinical trials ${ }^{[65-67]}$. The second study examined therapeutic miRNA-based drugs through the use of synthetic miRNA mimics. Recently, a phase I clinical trial using the miRNA mimic MIRX34 (Mirna Therapeutics, Inc.) was performed ${ }^{[68]}$. MIRX34 is a synthetic miRNA mimic of the tumor suppressor miR-34 and was administered to patients with primary or metastatic liver cancer. This trial was ended because of serious adverse immune-related effects. The administration of tumor-suppressor miRNA mimics continues to bear undesirable risks and negative, unexpected physiological effects because multiple genes, regulating multiple biological functions, can be impacted by miRNAs. Restoring tumor-suppressor miRNAs, which are abundantly detected in the plasma/serum of healthy individuals but lowered in patients with cancer [Table 2], may minimize the physiological risks of systemic administration. We recently reported that restoring and maintaining the miR-107 plasma level significantly inhibited tumor progression in mice ${ }^{[61]}$. The systemic delivery of tumor-suppressor miRNAs in gastric cancer patients may thus provide significant advantages because effects can be repeatedly examined repeatedly using blood-based miRNA levels.

\section{CONCLUSION}

The development of liquid biopsy-based analyses could improve diagnosis and therapy for patients with gastric cancer. As a liquid biopsy, circulating miRNAs have the potential to diagnose gastric cancer at an early stage, predict prognosis and recurrence, evaluate patient status and therapeutic efficacy, and provide optimal, individualized treatment strategies. It should be noted that the present review is limited by examining a relatively small number of retrospective cohort studies. Additional research with large cohorts or prospective clinical trials with longer follow-up periods are therefore necessary to confirm the usefulness of candidate miRNAs. Translation into clinically useful gastric cancer treatments also requires significant additional work. The physiological effects of tumor-suppressor miRNAs must be examined in greater detail before they can be safely administered systemically, and their tumor-suppressive functions must be validated in vivo before clinical use. Delivery systems for miRNAs must be further refined to surmount problems such as cellular uptake and bloodstream stability. Finally, more powerful anticancer tumor-suppressor miRNAs should be found by examining the plasma of patients with different cancers, through methods such as microarray analysis, next-generation sequencing, and digital PCR-based approaches. Currently under evaluation, these strategies will likely provide the future's next innovations.

\section{DECLARATIONS}

\section{Authors' contributions}

Designed the research and wrote the paper: Komatsu S

Collected the data and performed data analyses: Komatsu S, Kiuchi J, Imamura T

Reviewed the paper: Komatsu S, Ichikawa D, Otsuji E

\section{Availability of data and materials}

Not applicable.

\section{Financial support and sponsorship}

None.

\section{Conflict of interest}

All authors declared that there are no conflicts of interest. 


\section{Ethical approval and consent to participate}

Not applicable.

\section{Consent for publication}

Not applicable.

\section{Copyright}

(c) The Author(s) 2018.

\section{REFERENCES}

1. Torre LA, Bray F, Siegel RL, Ferlay J, Lortet-Tieulent J, Jemal A. Global cancer statistics, 2012. CA Cancer J Clin 2015;65:87-108.

2. Van Cutsem E, Sagaert X, Topal B, Haustermans K, Prenen H. Gastric cancer. Lancet 2016;388:2654-64.

3. Bang YJ, Van Cutsem E, Feyereislova A, Chung HC, Shen L, Sawaki A, Lordick F, Ohtsu A, Omuro Y, Satoh T, Aprile G, Kulikov E, Hill J, Lehle M, Rüschoff J, Kang YK; ToGA Trial Investigators. Trastuzumab in combination with chemotherapy versus chemotherapy alone for treatment of HER2-positive advanced gastric or gastro-oesophageal junction cancer (ToGA): a phase 3, open-label, randomised controlled trial. Lancet 2010;376:687-97.

4. Lordick F, Kang YK, Chung HC, Salman P, Oh SC, Bodoky G, Kurteva G, Volovat C, Moiseyenko VM, Gorbunova V, Park JO, Sawaki A, Celik I, Götte H, Melezínková H, Moehler M; Arbeitsgemeinschaft Internistische Onkologie and EXPAND Investigators. Capecitabine and cisplatin with or without cetuximab for patients with previously untreated advanced gastric cancer (EXPAND): a randomised, openlabel phase 3 trial. Lancet Oncol 2013;14:490-9.

5. Waddell T, Chau I, Cunningham D, Gonzalez D, Okines AF, Okines C, Wotherspoon A, Saffery C, Middleton G, Wadsley J, Ferry D, Mansoor W, Crosby T, Coxon F, Smith D, Waters J, Iveson T, Falk S, Slater S, Peckitt C, Barbachano Y. Epirubicin, oxaliplatin, and capecitabine with or without panitumumab for patients with previously untreated advanced oesophagogastric cancer (REAL3): a randomised, open-label phase 3 trial. Lancet Oncol 2013;14:481-9.

6. Satoh T, Xu RH, Chung HC, Sun GP, Doi T, Xu JM, Tsuji A, Omuro Y, Li J, Wang JW, Miwa H, Qin SK, Chung IJ, Yeh KH, Feng JF, Mukaiyama A, Kobayashi M, Ohtsu A, Bang YJ. Lapatinib plus paclitaxel versus paclitaxel alone in the second-line treatment of HER2amplified advanced gastric cancer in Asian populations: TyTAN--a randomized, phase III study. J Clin Oncol 2014;32:2039-49.

7. Fuchs CS, Tomasek J, Yong CJ, Dumitru F, Passalacqua R, Goswami C, Safran H, Dos Santos LV, Aprile G, Ferry DR, Melichar B, Tehfe M, Topuzov E, Zalcberg JR, Chau I, Campbell W, Sivanandan C, Pikiel J, Koshiji M, Hsu Y, Liepa AM, Gao L, Schwartz JD, Tabernero J; REGARD Trial Investigators. Ramucirumab monotherapy for previously treated advanced gastric or gastro-oesophageal junction adenocarcinoma (REGARD): an international, randomised, multicentre, placebo-controlled, phase 3 trial. Lancet 2014;383:31-9.

8. Li TT, Liu H, Yu J, Shi GY, Zhao LY, Li GX. Prognostic and predictive blood biomarkers in gastric cancer and the potential application of circulating tumor cells. World J Gastroenterol 2018;24:2236-46.

9. Pantel K, Alix-Panabieres C. Real-time liquid biopsy in cancer patients: fact or fiction? Cancer Res 2013;73:6384-8.

10. Schwarzenbach H, Hoon DS, Pantel K. Cell-free nucleic acids as biomarkers in cancer patients. Nat Rev Cancer 2011;11:426-37.

11. van de Stolpe A, Pantel K, Sleijfer S, Terstappen LW, den Toonder JM. Circulating tumor cell isolation and diagnostics: toward routine clinical use. Cancer Res 2011;71:5955-60.

12. Alix-Panabieres C, Pantel K. Circulating tumor cells: liquid biopsy of cancer. Clin Chem 2013;59:110-8

13. Crowley E, Di Nicolantonio F, Loupakis F, Bardelli A. Liquid biopsy: monitoring cancer-genetics in the blood. Nat Rev Clin Oncol 2013;10:472-84.

14. Lee RC, Feinbaum RL, Ambros V. The C. elegans heterochronic gene lin-4 encodes small RNAs with antisense complementarity to lin14. Cell 1993;75:843-54.

15. He L, Thomson JM, Hemann MT, Hernando-Monge E, Mu D, Goodson S, Powers S, Cordon-Cardo C, Lowe SW, Hannon GJ, Hammond SM. A microRNA polycistron as a potential human oncogene. Nature 2005;435:828-33.

16. Calin GA, Croce CM. MicroRNA signatures in human cancers. Nat Rev Cancer 2006;6:857-66.

17. He L, He X, Lim LP, de Stanchina E, Xuan Z, Liang Y, Xue W, Zender L, Magnus J, Ridzon D, Jackson AL, Linsley PS, Chen C, Lowe SW, Cleary MA, Hannon GJ. A microRNA component of the p53 tumour suppressor network. Nature 2007;447:1130-4.

18. Lu J, Getz G, Miska EA, Alvarez-Saavedra E, Lamb J, Peck D, Sweet-Cordero A, Ebert BL, Mak RH, Ferrando AA, Downing JR, Jacks T, Horvitz HR, Golub TR. MicroRNA expression profiles classify human cancers. Nature 2005;435:834-8.

19. Mitchell PS, Parkin RK, Kroh EM, Fritz BR, Wyman SK, Pogosova-Agadjanyan EL, Peterson A, Noteboom J, O’Briant KC, Allen A, Lin DW, Urban N, Drescher CW, Knudsen BS, Stirewalt DL, Gentleman R, Vessella RL, Nelson PS, Martin DB, Tewari M. Circulating microRNAs as stable blood-based markers for cancer detection. Proc Natl Acad Sci U S A 2008;105:10513-8.

20. Chen X, Ba Y, Ma L, Cai X, Yin Y, Wang K, Guo J, Zhang Y, Chen J, Guo X, Li Q, Li X, Wang W, Zhang Y, Wang J, Jiang X, Xiang Y, Xu C, Zheng P, Zhang J, Li R, Zhang H, Shang X, Gong T, Ning G, Wang J, Zen K, Zhang J, Zhang CY. Characterization of microRNAs in serum: a novel class of biomarkers for diagnosis of cancer and other diseases. Cell Res 2008;18:997-1006.

21. Filipowicz W, Bhattacharyya SN, Sonenberg N. Mechanisms of post-transcriptional regulation by microRNAs: are the answers in sight? Nat Rev Genet 2008;9:102-14. 
22. Ichikawa D, Komatsu S, Konishi H, Otsuji E. Circulating microRNA in digestive tract cancers. Gastroenterology 2012;142:1074-8.e1071.

23. Arroyo JD, Chevillet JR, Kroh EM, Ruf IK, Pritchard CC, Gibson DF, Mitchell PS, Bennett CF, Pogosova-Agadjanyan EL, Stirewalt DL, Tait JF, Tewari M. Argonaute2 complexes carry a population of circulating microRNAs independent of vesicles in human plasma. Proc Natl Acad Sci U S A 2011;108:5003-8.

24. Vickers KC, Palmisano BT, Shoucri BM, Shamburek RD, Remaley AT. MicroRNAs are transported in plasma and delivered to recipient cells by high-density lipoproteins. Nat Cell Biol 2011;13:423-33.

25. Kosaka N, Iguchi H, Ochiya T. Circulating microRNA in body fluid: a new potential biomarker for cancer diagnosis and prognosis. Cancer Sci 2010;101:2087-92.

26. Hasselmann DO, Rappl G, Tilgen W, Reinhold U. Extracellular tyrosinase mRNA within apoptotic bodies is protected from degradation in human serum. Clin Chem 2001;47:1488-9.

27. Cocucci E, Racchetti G, Meldolesi J. Shedding microvesicles: artefacts no more. Trends Cell Biol 2009;19:43-51.

28. Valadi H, Ekstrom K, Bossios A, Sjostrand M, Lee JJ, Lotvall JO. Exosome-mediated transfer of mRNAs and microRNAs is a novel mechanism of genetic exchange between cells. Nat Cell Biol 2007;9:654-9.

29. Kosaka N, Iguchi H, Yoshioka Y, Takeshita F, Matsuki Y, Ochiya T. Secretory mechanisms and intercellular transfer of microRNAs in living cells. J Biol Chem 2010;285:17442-52.

30. Skog J, Wurdinger T, van Rijn S, Meijer DH, Gainche L, Sena-Esteves M, Curry WT, Jr., Carter BS, Krichevsky AM, Breakefield XO. Glioblastoma microvesicles transport RNA and proteins that promote tumour growth and provide diagnostic biomarkers. Nat Cell Biol 2008;10:1470-6.

31. Rechavi O, Erlich Y, Amram H, Flomenblit L, Karginov FV, Goldstein I, Hannon GJ, Kloog Y. Cell contact-dependent acquisition of cellular and viral nonautonomously encoded small RNAs. Genes Dev 2009;23:1971-9.

32. Tsujiura M, Ichikawa D, Komatsu S, Shiozaki A, Takeshita H, Kosuga T, Konishi H, Morimura R, Deguchi K, Fujiwara H, Okamoto K, Otsuji E. Circulating microRNAs in plasma of patients with gastric cancers. Br J Cancer 2010;102:1174-9.

33. Morimura R, Komatsu S, Ichikawa D, Takeshita H, Tsujiura M, Nagata H, Konishi H, Shiozaki A, Ikoma H, Okamoto K, Ochiai T, Taniguchi H, Otsuji E. Novel diagnostic value of circulating miR-18a in plasma of patients with pancreatic cancer. Br J Cancer 2011;105:1733-40.

34. Komatsu S, Ichikawa D, Takeshita H, Konishi H, Nagata H, Hirajima S, Kawaguchi T, Arita T, Shiozaki A, Fujiwara H, Okamoto K, Otsuji E. Prognostic impact of circulating miR-21 and miR-375 in plasma of patients with esophageal squamous cell carcinoma. Expert Opin Biol Ther 2012;12 Suppl 1:S53-9.

35. Kawaguchi T, Komatsu S, Ichikawa D, Morimura R, Tsujiura M, Konishi H, Takeshita H, Nagata H, Arita T, Hirajima S, Shiozaki A, Ikoma H, Okamoto K, Ochiai T, Taniguchi H, Otsuji E. Clinical impact of circulating miR-221 in plasma of patients with pancreatic cancer. Br J Cancer 2013;108:361-9.

36. Hirajima S, Komatsu S, Ichikawa D, Takeshita H, Konishi H, Shiozaki A, Morimura R, Tsujiura M, Nagata H, Kawaguchi T, Arita T, Kubota T, Fujiwara H, Okamoto K, Otsuji E. Clinical impact of circulating miR-18a in plasma of patients with oesophageal squamous cell carcinoma. Br J Cancer 2013;108:1822-9.

37. Komatsu S, Ichikawa D, Hirajima S, Kawaguchi T, Miyamae M, Okajima W, Ohashi T, Arita T, Konishi H, Shiozaki A, Fujiwara H, Okamoto K, Yagi N, Otsuji E. Plasma microRNA profiles: identification of miR-25 as a novel diagnostic and monitoring biomarker in oesophageal squamous cell carcinoma. Br J Cancer 2014;111:1614-24.

38. Komatsu S, Ichikawa D, Miyamae M, Kawaguchi T, Morimura R, Hirajima S, Okajima W, Ohashi T, Imamura T, Konishi H, Shiozaki A, Ikoma H, Okamoto K, Taniguchi H, Otsuji E. Malignant potential in pancreatic neoplasm; new insights provided by circulating miR-223 in plasma. Expert Opin Biol Ther 2015;15:773-85.

39. Miyamae M, Komatsu S, Ichikawa D, Kawaguchi T, Hirajima S, Okajima W, Ohashi T, Imamura T, Konishi H, Shiozaki A, Moriumura R, Ikoma H, Okamoto K, Taniguchi H, Itoh Y, Otsuji E. Plasma microRNA profiles: identification of miR-744 as a novel diagnostic and prognostic biomarker in pancreatic cancer. Br J Cancer 2015;113:1467-76.

40. Tsujiura M, Komatsu S, Ichikawa D, Shiozaki A, Konishi H, Takeshita H, Moriumura R, Nagata H, Kawaguchi T, Hirajima S, Arita T, Fujiwara H, Okamoto K, Otsuji E. Circulating miR-18a in plasma contributes to cancer detection and monitoring in patients with gastric cancer. Gastric Cancer 2015;18:271-9.

41. Kawaguchi T, Komatsu S, Ichikawa D, Tsujiura M, Takeshita H, Hirajima S, Miyamae M, Okajima W, Ohashi T, Imamura T, Kiuchi J, Konishi H, Shiozaki A, Okamoto K, Otsuji E. Circulating MicroRNAs: A Next-Generation Clinical Biomarker for Digestive System Cancers. Int J Mol Sci 2016;17:E1459.

42. Komatsu S, Ichikawa D, Kawaguchi T, Miyamae M, Okajima W, Ohashi T, Imamura T, Kiuchi J, Konishi H, Shiozaki A, Moriumura R, Ikoma H, Okamoto K, Taniguchi H, Itoh Y, Otsuji E. Circulating miR-21 as an independent predictive biomarker for chemoresistance in esophageal squamous cell carcinoma. Am J Cancer Res 2016;6:1511-23.

43. Komatsu S, Ichikawa D, Kawaguchi T, Takeshita H, Miyamae M, Ohashi T, Okajima W, Imamura T, Kiuchi J, Arita T, Konishi H, Shiozaki A, Fujiwara H, Okamoto K, Otsuji E. Plasma microRNA profiles: identification of miR-23a as a novel biomarker for chemoresistance in esophageal squamous cell carcinoma. Oncotarget 2016;7:62034-48.

44. Okajima W, Komatsu S, Ichikawa D, Miyamae M, Kawaguchi T, Hirajima S, Ohashi T, Imamura T, Kiuchi J, Arita T, Konishi H, Shiozaki A, Moriumura R, Ikoma H, Okamoto K, Taniguchi H, Itoh Y, Otsuji E. Circulating microRNA profiles in plasma: identification of miR-224 as a novel diagnostic biomarker in hepatocellular carcinoma independent of hepatic function. Oncotarget 2016;7:53820-36.

45. Komatsu S, Ichikawa D, Takeshita H, Tsujiura M, Morimura R, Nagata H, Kosuga T, Iitaka D, Konishi H, Shiozaki A, Fujiwara H, Okamoto K, Otsuji E. Circulating microRNAs in plasma of patients with oesophageal squamous cell carcinoma. Br J Cancer 
2011;105:104-11.

46. Konishi H, Ichikawa D, Komatsu S, Shiozaki A, Tsujiura M, Takeshita H, Morimura R, Nagata H, Arita T, Kawaguchi T, Hirashima S, Fujiwara H, Okamoto K, Otsuji E. Detection of gastric cancer-associated microRNAs on microRNA microarray comparing pre- and postoperative plasma. Br J Cancer 2012;106:740-7.

47. Liu H, Zhu L, Liu B, Yang L, Meng X, Zhang W, Ma Y, Xiao H. Genome-wide microRNA profiles identify miR-378 as a serum biomarker for early detection of gastric cancer. Cancer Lett 2012;316:196-203.

48. Zheng Y, Cui L, Sun W, Zhou H, Yuan X, Huo M, Chen J, Lou Y, Guo J. MicroRNA-21 is a new marker of circulating tumor cells in gastric cancer patients. Cancer Biomark 2011;10:71-7.

49. Valladares-Ayerbes M, Reboredo M, Medina-Villaamil V, Iglesias-Diaz P, Lorenzo-Patino MJ, Haz M, Santamarina I, Blanco M, Fernandez-Tajes J, Quindos M, Carral A, Figueroa A, Antón-Aparicio LM, Calvo L. Circulating miR-200c as a diagnostic and prognostic biomarker for gastric cancer. J Transl Med 2012;10:186.

50. Wu J, Li G, Yao Y, Wang Z, Sun W, Wang J. MicroRNA-421 is a new potential diagnosis biomarker with higher sensitivity and specificity than carcinoembryonic antigen and cancer antigen 125 in gastric cancer. Biomarkers 2015;20:58-63.

51. Li C, Li JF, Cai Q, Qiu QQ, Yan M, Liu BY, Zhu ZG. MiRNA-199a-3p: a potential circulating diagnostic biomarker for early gastric cancer. J Surg Oncol 2013;108:89-92.

52. Chen Q, Ge X, Zhang Y, Xia H, Yuan D, Tang Q, Chen L, Pang X, Leng W, Bi F. Plasma miR-122 and miR-192 as potential novel biomarkers for the early detection of distant metastasis of gastric cancer. Oncol Rep 2014;31:1863-70.

53. Fu Z, Qian F, Yang X, Jiang H, Chen Y, Liu S. Circulating miR-222 in plasma and its potential diagnostic and prognostic value in gastric cancer. Med Oncol 2014;31:164.

54. Komatsu S, Ichikawa D, Tsujiura M, Konishi H, Takeshita H, Nagata H, Kawaguchi T, Hirajima S, Arita T, Shiozaki A, Kubota T, Fujiwara H, Okamoto K, Otsuji E. Prognostic impact of circulating miR-21 in the plasma of patients with gastric carcinoma. Anticancer Res 2013;33:271-6.

55. Zhu C, Ren C, Han J, Ding Y, Du J, Dai N, Dai J, Ma H, Hu Z, Shen H, Xu Y, Jin G. A five-microRNA panel in plasma was identified as potential biomarker for early detection of gastric cancer. Br J Cancer 2014;110:2291-9.

56. Liu X, Kwong A, Sihoe A, Chu KM. Plasma miR-940 may serve as a novel biomarker for gastric cancer. Tumour Biol 2016;37:3589-97.

57. Wu J, Li G, Wang Z, Yao Y, Chen R, Pu X, Wang J. Circulating microRNA-21 is a potential diagnostic biomarker in gastric cancer. Dis Markers 2015;2015:435656.

58. Zhang J, Song Y, Zhang C, Zhi X, Fu H, Ma Y, Chen Y, Pan F, Wang K, Ni J, Jin W, He X, Su H, Cui D. Circulating MiR-16-5p and MiR$19 b-3 p$ as two novel potential biomarkers to indicate progression of gastric cancer. Theranostics 2015;5:733-45.

59. Kosaka N, Iguchi H, Yoshioka Y, Hagiwara K, Takeshita F, Ochiya T. Competitive interactions of cancer cells and normal cells via secretory microRNAs. J Biol Chem 2012;287:1397-405.

60. Kosaka N, Iguchi H, Hagiwara K, Yoshioka Y, Takeshita F, Ochiya T. Neutral sphingomyelinase 2 (nSMase2)-dependent exosomal transfer of angiogenic microRNAs regulate cancer cell metastasis. J Biol Chem 2013;288:10849-59.

61. Imamura T, Komatsu S, Ichikawa D, Miyamae M, Okajima W, Ohashi T, Kiuchi J, Nishibeppu K, Konishi H, Shiozaki A, Morimura R, Ikoma H, Ochiai T, Okamoto K, Taniguchi H, Otsuji E. Depleted tumor suppressor miR-107 in plasma relates to tumor progression and is a novel therapeutic target in pancreatic cancer. Sci Rep 2017;7:5708.

62. Imaoka H, Toiyama Y, Okigami M, Yasuda H, Saigusa S, Ohi M, Tanaka K, Inoue Y, Mohri Y, Kusunoki M. Circulating microRNA-203 predicts metastases, early recurrence, and poor prognosis in human gastric cancer. Gastric Cancer 2016;19:744-53.

63. Li A, Yu J, Kim H, Wolfgang CL, Canto MI, Hruban RH, Goggins M. MicroRNA array analysis finds elevated serum miR-1290 accurately distinguishes patients with low-stage pancreatic cancer from healthy and disease controls. Clin Cancer Res 2013;19:3600-10.

64. Takeshita N, Hoshino I, Mori M, Akutsu Y, Hanari N, Yoneyama Y, Ikeda N, Isozaki Y, Maruyama T, Akanuma N, Komatsu A, Jitsukawa M, Matsubara H. Serum microRNA expression profile: miR-1246 as a novel diagnostic and prognostic biomarker for oesophageal squamous cell carcinoma. Br J Cancer 2013;108:644-52.

65. Ma L, Reinhardt F, Pan E, Soutschek J, Bhat B, Marcusson EG, Teruya-Feldstein J, Bell GW, Weinberg RA. Therapeutic silencing of miR-10b inhibits metastasis in a mouse mammary tumor model. Nat Biotechnol 2010;28:341-7.

66. Gebert LF, Rebhan MA, Crivelli SE, Denzler R, Stoffel M, Hall J. Miravirsen (SPC3649) can inhibit the biogenesis of miR-122. Nucleic Acids Res 2014;42:609-21.

67. Lanford RE, Hildebrandt-Eriksen ES, Petri A, Persson R, Lindow M, Munk ME, Kauppinen S, Orum H. Therapeutic silencing of microRNA-122 in primates with chronic hepatitis C virus infection. Science 2010;327:198-201.

68. Bouchie A. First microRNA mimic enters clinic. Nat Biotechnol 2013;31:577.

69. Wang H, Wang L, Wu Z, Sun R, Jin H, Ma J, Liu L, Ling R, Yi J, Wang L, Bian J, Chen J, Li N, Yuan S, Yun J. Three dysregulated microRNAs in serum as novel biomarkers for gastric cancer screening. Med Oncol 2014;31:298.

70. Wang M, Gu H, Wang S, Qian H, Zhu W, Zhang L, Zhao C, Tao Y, Xu W. Circulating miR-17-5p and miR-20a: molecular markers for gastric cancer. Mol Med Rep 2012;5:1514-20.

71. Zhou H, Guo JM, Lou YR, Zhang XJ, Zhong FD, Jiang Z, Cheng J, Xiao BX. Detection of circulating tumor cells in peripheral blood from patients with gastric cancer using microRNA as a marker. J Mol Med (Berl) 2010;88:709-17.

72. Cai H, Yuan Y, Hao YF, Guo TK, Wei X, Zhang YM. Plasma microRNAs serve as novel potential biomarkers for early detection of gastric cancer. Med Oncol 2013;30:452.

73. Zhou X, Zhu W, Li H, Wen W, Cheng W, Wang F, Wu Y, Qi L, Fan Y, Chen Y, Ding Y, Xu J, Qian J, Huang Z, Wang T, Zhu D, Shu Y, Liu P. Diagnostic value of a plasma microRNA signature in gastric cancer: a microRNA expression analysis. Sci Rep 2015;5:11251. 
74. Yang R, Fu Y, Zeng Y, Xiang M, Yin Y, Li L, Xu H, Zhong J, Zeng X. Serum miR-20a is a promising biomarker for gastric cancer. Biomed Rep 2017;6:429-34.

75. Li BS, Zhao YL, Guo G, Li W, Zhu ED, Luo X, Mao XH, Zou QM, Yu PW, Zuo QF, Li N, Tang B, Liu KY, Xiao B. Plasma microRNAs, miR-223, miR-21 and miR-218, as novel potential biomarkers for gastric cancer detection. PLoS One 2012;7:e41629.

76. Wang B, Zhang Q. The expression and clinical significance of circulating microRNA-21 in serum of five solid tumors. J Cancer Res Clin Oncol 2012;138:1659-66.

77. Shiotani A, Murao T, Kimura Y, Matsumoto H, Kamada T, Kusunoki H, Inoue K, Uedo N, Iishi H, Haruma K. Identification of serum miRNAs as novel non-invasive biomarkers for detection of high risk for early gastric cancer. Br J Cancer 2013;109:2323-30.

78. Song J, Bai Z, Zhang J, Meng H, Cai J, Deng W, Bi J, Ma X, Zhang Z. Serum microRNA-21 levels are related to tumor size in gastric cancer patients but cannot predict prognosis. Oncol Lett 2013;6:1733-7.

79. Huang S, Wang J, Li J, Luo Q, Zhao M, Zheng L, Dong X, Chen C, Che Y, Liu P, Qi J, Huang C. Serum microRNA expression profile as a diagnostic panel for gastric cancer. Jpn J Clin Oncol 2016;46:811-8.

80. Sierzega M, Kaczor M, Kolodziejczyk P, Kulig J, Sanak M, Richter P. Evaluation of serum microRNA biomarkers for gastric cancer based on blood and tissue pools profiling: the importance of miR-21 and miR-331. Br J Cancer 2017;117:266-73.

81. Zhuang K, Han K, Tang H, Yin X, Zhang J, Zhang X, Zhang L. Up-regulation of plasma miR-23b is associated with poor prognosis of gastric cancer. Med Sci Monit 2016;22:356-61.

82. Zhang R, Wang W, Li F, Zhang H, Liu J. MicroRNA-106b 25 expressions in tumor tissues and plasma of patients with gastric cancers. Med Oncol 2014;31:243.

83. Li F, Guo Y, Liu J, Zhang R. The significance of elevated plasma expression of microRNA 106b 25 clusters in gastric cancer. PLoS One 2017;12:e178427.

84. Ayremlou N, Mozdarani H, Mowla SJ, Delavari A. Increased levels of serum and tissue miR-107 in human gastric cancer: Correlation with tumor hypoxia. Cancer Biomark 2015;15:851-60.

85. Cui MH, Hou XL, Lei XY, Mu FH, Yang GB, Yue L, Fu Y, Yi GX. Upregulation of microRNA 181c expression in gastric cancer tissues and plasma. Asian Pac J Cancer Prev 2013;14:3063-6.

86. Peng WZ, Ma R, Wang F, Yu J, Liu ZB. Role of miR-191/425 cluster in tumorigenesis and diagnosis of gastric cancer. Int J Mol Sci 2014;15:4031-48.

87. Li C, Li JF, Cai Q, Qiu QQ, Yan M, Liu BY, Zhu ZG. miRNA-199a-3p in plasma as a potential diagnostic biomarker for gastric cancer. Ann Surg Oncol 2013;20 Suppl 3:S397-405.

88. Zhang HP, Sun FB, Li SJ. Serum miR-200c expression level as a prognostic biomarker for gastric cancer. Genet Mol Res 2015;14:1591320.

89. Lo SS, Hung PS, Chen JH, Tu HF, Fang WL, Chen CY, Chen WT, Gong NR, Wu CW. Overexpression of miR-370 and downregulation of its novel target TGFbeta-RII contribute to the progression of gastric carcinoma. Oncogene 2012;31:226-37.

90. Song J, Yin J, Bai Z, Zhang J, Meng H, Cai J, Deng W, Ma X, Zhang Z. The profile of serum microRNAs predicts prognosis for resected gastric cancer patients receiving platinum-based chemotherapy. Dig Dis Sci 2017;62:1223-34.

91. Zeng Q, Jin C, Chen W, Xia F, Wang Q, Fan F, Du J, Guo Y, Lin C, Yang K, Li J, Peng X, Li X, Cao K. Downregulation of serum miR17 and miR-106b levels in gastric cancer and benign gastric diseases. Chin J Cancer Res 2014;26:711-6.

92. Qiu X, Zhang J, Shi W, Liu S, Kang M, Chu H, Wu D, Tong N, Gong W, Tao G, Zhao Q, Qiang F, Zhu H, Wu Q, Wang M, Zhang Z. Circulating microRNA-26a in plasma and its potential diagnostic value in gastric cancer. PLoS One 2016;11:e0151345.

93. Shen YH, Xie ZB, Yue AM, Wei QD, Zhao HF, Yin HD, Mai W, Zhong XG, Huang SR. Expression level of microRNA-195 in the serum of patients with gastric cancer and its relationship with the clinicopathological staging of the cancer. Eur Rev Med Pharmacol Sci 2016;20:1283-7.

94. Gorur A, Balci Fidanci S, Dogruer Unal N, Ayaz L, Akbayir S, Yildirim Yaroglu H, Dirlik M, Serin MS, Tamer L. Determination of plasma microRNA for early detection of gastric cancer. Mol Biol Rep 2013;40:2091-6.

95. Chen X, Liu XS, Liu HY, Lu YY, Li Y. Reduced expression of serum miR-204 predicts poor prognosis of gastric cancer. Genet Mol Res 2016;15.

96. Hou CG, Luo XY, Li G. Diagnostic and prognostic value of serum microRNA-206 in patients with gastric cancer. Cell Physiol Biochem 2016, 39:1512-20.

97. Xin SY, Feng XS, Zhou LQ, Sun JJ, Gao XL, Yao GL. Reduced expression of circulating microRNA-218 in gastric cancer and correlation with tumor invasion and prognosis. World J Gastroenterol 2014;20:6906-11.

98. Zhang WH, Gui JH, Wang CZ, Chang Q, Xu SP, Cai CH, Li YN, Tian YP, Yan L, Wu B. The identification of miR-375 as a potential biomarker in distal gastric adenocarcinoma. Oncol Res 2012;20:139-47.

99. Wu D, Cao G, Huang Z, Jin K, Hu H, Yu J, Zeng Y. Decreased miR-503 expression in gastric cancer is inversely correlated with serum carcinoembryonic antigen and acts as a potential prognostic and diagnostic biomarker. Onco Targets Ther 2017;10:129-35.

100. Wang WN, Chen Y, Zhang YD, Hu TH. The regulatory mechanism of CCR7 gene expression and its involvement in the metastasis and progression of gastric cancer. Tumour Biol 2013;34:1865-71.

101. Iorio MV, Croce CM. MicroRNA dysregulation in cancer: diagnostics, monitoring and therapeutics. A comprehensive review. EMBO Mol Med 2012;4:143-59. 